\title{
Assessing the Toxicity and Mitigating the Impact of Harmful Prymnesium Blooms in Eutrophic Waters of the Norfolk Broads
}

\author{
Ben A. Wagstaff,* Jennifer Pratscher,* Peter Paolo L. Rivera, Edward S. Hems, Elliot Brooks, \\ Martin Rejzek, Jonathan D. Todd, J. Colin Murrell, and Robert A. Field
}

Cite This: https://doi.org/10.1021/acs.est.1c04742

Read Online

ACCESS

Џll Metrics \& More

四 Article Recommendations

Supporting Information

ABSTRACT: Prymnesium parvum is a toxin-producing microalga, which causes harmful algal blooms globally, frequently leading to massive fish kills that have adverse ecological and economic implications for natural waterways and aquaculture alike. The dramatic effects observed on fish are thought to be due to algal polyether toxins, known as the prymnesins, but their lack of environmental detection has resulted in an uncertainty about the true ichthyotoxic agents. Using qPCR, we found elevated levels of $P$. parvum and its lytic virus, PpDNAV-BW1, in a fish-killing bloom on the Norfolk Broads, United Kingdom, in March 2015. We also detected, for the first time, the B-type prymnesin toxins in Broads waterway samples and gill tissue isolated from a dead fish taken

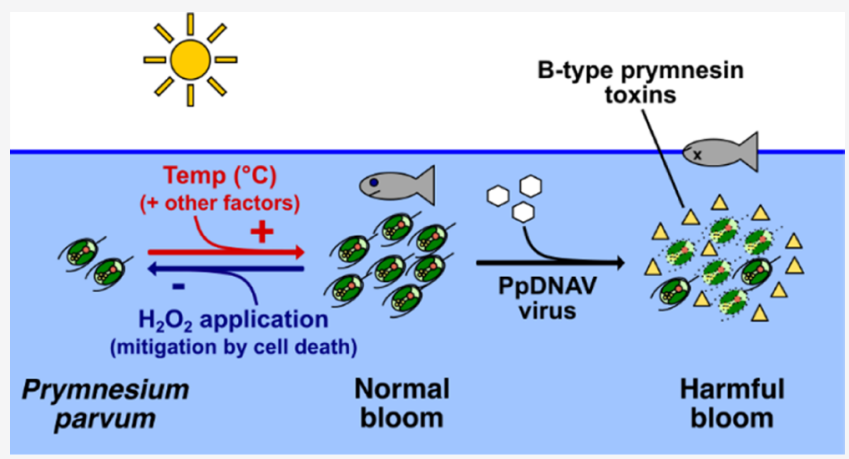
from the study site. Furthermore, Norfolk Broads $P$. parvum isolates unambiguously produced B-type toxins in laboratory-grown cultures. A 2 year longitudinal study of the Broads study site showed P. parvum blooms to be correlated with increased temperature and that PpDNAV plays a significant role in $P$. parvum bloom demise. Finally, we used a field trial to show that treatment with low doses of hydrogen peroxide represents an effective strategy to mitigate blooms of $P$. parvum in enclosed water bodies.

KEYWORDS: Prymnesium parvum, harmful algal blooms, bloom microbiome, eutrophic lakes, fish kill, environmental viruses, prymnesin toxins

\section{INTRODUCTION}

In a world with a rapidly growing human population, it has been estimated that since 1961 the average annual increase in consumption of fish (3.2\%) has outpaced human population growth (1.6\%), with further increased demand expected for the coming decade. ${ }^{1}$ This demand will be met by aquaculture, with an expected net decrease in wild fish consumption during this period. ${ }^{1}$ Harmful algal blooms (HABs) not only damage natural environments but also represent a major threat to aquaculture; the rapid spread of algae can lead to fish stock losses through the release of algal toxins, mechanical damage to gills, or water hypoxia associated with bloom collapse. ${ }^{2}$ One group of microalgae known for their bloom-forming ability are the haptophytes, made famous by the coccolithophore Emiliania huxleyi, which forms blooms tens of kilometers wide that can be seen readily by satellite imagery due to the reflective properties of its coccoliths. ${ }^{3}$ On the other hand, the Prymnesium genus of the haptophytes has gained attention due to its HABs that damage fish stocks globally, in both aquaculture and capture fishery industries. ${ }^{4}$

Often referred to as "golden algae", Prymnesium parvum has caused particular issues for aquaculture in North America in the last 2 decades. As a result, the biotic factors that impact $P$. parvum growth and toxicity have been studied extensively in laboratory settings. ${ }^{5-7}$ Although there has been speculation regarding the toxic entity responsible for fish deaths, ${ }^{8}$ an increasing body of research has been focused on the ichthyotoxins (prymnesins) due to their structural similarity to other ladder-frame polyether phycotoxins.' However, the prymnesins have not previously been detected in a natural setting. First isolated by Igarashi and co-workers in $1995,{ }^{10-12}$ the prymnesins are a group of polyketide metabolites that display potent ichthyotoxicity (Figure 1). Since their discovery, a chemically diverse family of prymnesins, including prymnesin$\mathrm{B} 1$, have been discovered, ${ }^{13-15}$ largely differing in the polyether core, glycosylation patterns, and level of chlorination of the toxins. More broadly, although research has identified certain environmental stimuli for bloom propagation, ${ }^{16}$ detailed molecular insights into natural Prymnesium blooms and their

Received: July 15, 2021

Revised: November 3, 2021

Accepted: November 5, 2021 

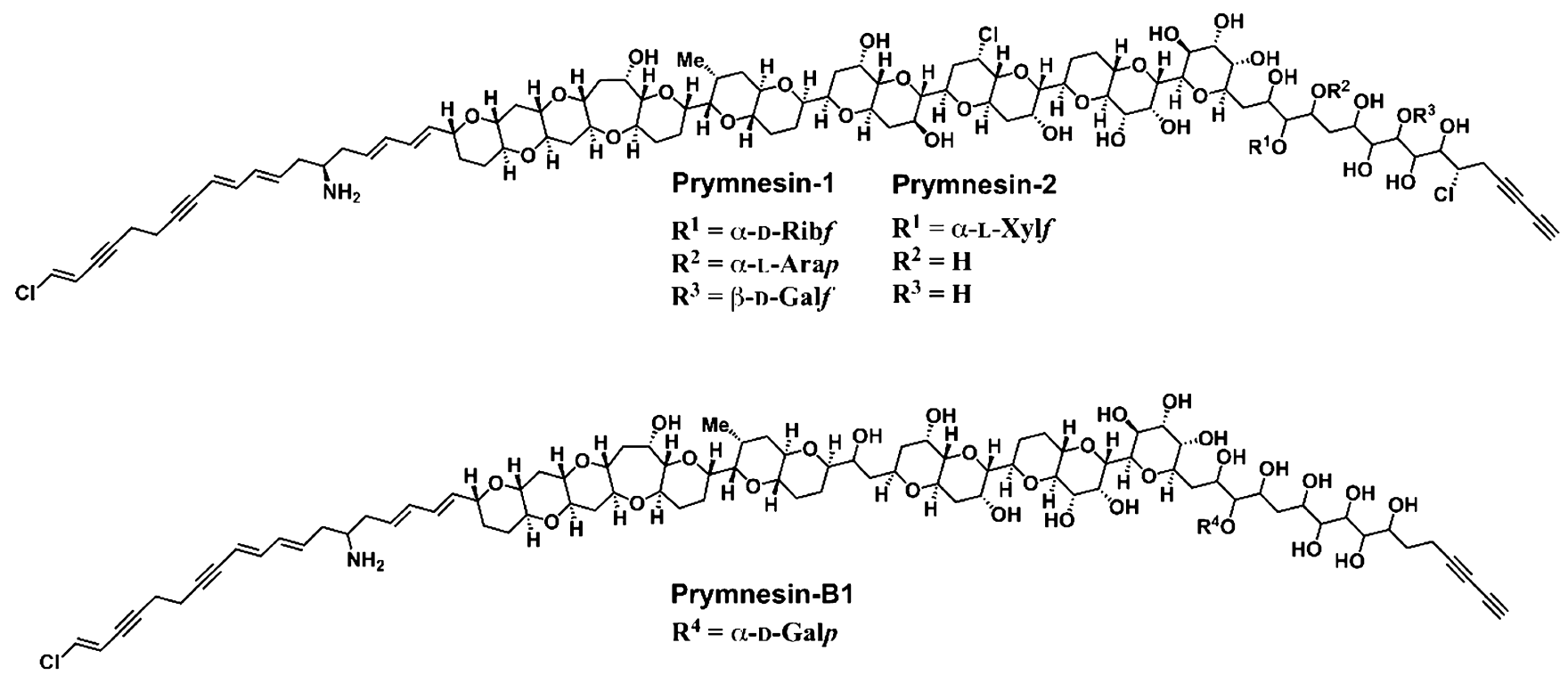

Figure 1. Chemical structure of prymnesin-1, -2, and -B1. ${ }^{10,13}$ Adapted from Hems et al. ${ }^{14}$

seasonal cycles is lacking. Furthermore, while it has been shown that the use of algaecides or the addition of clay flocculants or barley straw can effectively kill or inhibit the growth of $P$. parvum, ${ }^{17-19}$ this research has yet to translate into effective strategies for combatting HABs.

Detailed studies of HABs of eukaryotic microalgae in the natural environment are limited and warrant investigation. Here, we investigated the effects of a $P$. parvum $\mathrm{HAB}$ on Hickling Broad, England, an area frequently plagued by blooms of this organism but where the responsible ichthyotoxins were not previously known. ${ }^{20,21}$ The Norfolk Broads are a shallow, manmade set of navigable brackish lakes arising from flooded peat extraction that date back to the 12 th century. These waterways are a haven for birds and other wildlife, and a tourist attraction that is used for boating and angling throughout the year. The Broads are thought to contribute approximately $£ 550$ million per year to the local economy, ${ }^{22}$ which is threatened by frequent blooms of cyanobacteria and P. parvum. Hickling Broad, in particular, has had recurrent blooms of $P$. parvum since they were first reported in the 1960s, but incidents are thought to date back to at least the early part of the 20th century. ${ }^{20}$

Using biochemical methods, we report for the first time the detection of trace levels of prymnesin toxins in natural water samples and gill cells of a dead fish recovered during the $P$. parvum bloom of 2015 on Hickling Broad. We support these findings by the isolation of the local strain of P. parvum found on Hickling Broad and the use of targeted metabolomics to conclusively show the production of the B-type prymnesins in these strains. Using molecular genetics approaches, we further illuminate the 2015 P. parvum toxic bloom microbial community and show how the composition of this differs during nonbloom conditions. Furthermore, we followed population dynamics of $P$. parvum and its lytic virus, PpDNAV-BW $1^{23}$ over a 2 year period. We conclude by showing that hydrogen peroxide provides an effective mitigation strategy for Prymnesium bloom incidents. This multidisciplinary study sheds light on natural bloom dynamics of an important fish pathogen and provides the basis for understanding and managing future Prymnesium blooms in enclosed water bodies.

\section{MATERIALS AND METHODS}

Study Site, Water Sampling, and Processing. Hickling Broad was chosen as a study site due to the repeated instances of P. parvum blooms ${ }^{20}$ and an active bloom incident in April 2015 that we were able to monitor. 11 sampling locations were initially chosen to cover a large area of the broad, which was later expanded to include sampling point 12 that is not included in some analyses (Figure 2). In addition to the bloom samples from April 2015, full sets of water samples from all sampling points on Hickling Broad were taken every 2-4 weeks from January 2016 until December 2017. For every sampling point, two sterile 50 $\mathrm{mL}$ Falcon tubes were filled with water $(100 \mathrm{~mL}$ total per sample) from $\sim 20 \mathrm{~cm}$ depth, making sure to exclude the surface layer. Biomass in Falcon tubes was pelleted by centrifugation at $3200 \mathrm{~g}$ and $4{ }^{\circ} \mathrm{C}$ for $10 \mathrm{~min}$. Duplicate pellets were resuspended in $1 \mathrm{~mL}$ of nuclease free water (Ambion, Thermo Fisher Scientific) and suspensions from the same sampling point were pooled. Cell suspensions were subsequently pelleted at $18,000 \mathrm{~g}$ at $4{ }^{\circ} \mathrm{C}$ for $10 \mathrm{~min}$, the supernatant was discarded or used for toxin analysis (see Toxin Detection using LC-MS), and cell pellets were flash frozen with liquid nitrogen and stored at -80 ${ }^{\circ} \mathrm{C}$ until further processing. In addition, for every sample, $\mathrm{pH}$, temperature, and conductivity measurements were recorded. Sampling maps were generated using the QGIS 2.18 package (http://qgis.osgeo.org) with the OSM standard map.

Nucleic Acid Extraction from Water Samples. Nucleic acids were extracted from water using a sodium dodecyl sulfate (SDS)-based protocol ${ }^{24}$ with minor modifications. The biomass pellet of $100 \mathrm{~mL}$ Hickling Broad water was added to a $2.0 \mathrm{~mL}$ screw-cap tube of Lysing matrix E beads (MP Biomedicals UK) and mixed with $1 \mathrm{~mL}$ of $2.5 \%$ SDS extraction buffer. Cells were lysed in a FastPrep instrument (MP Biomedicals UK) for $45 \mathrm{~s}$ at $6.0 \mathrm{~m} \mathrm{~s}^{-1}$ and supernatants were extracted twice using phenol/ chloroform/isoamyl alcohol (25:24:1) and chloroform/isoamyl alcohol (24:1). Nucleic acids were precipitated with polyethylene glycol 6000 solution (20\%) and dissolved in $100 \mu \mathrm{L}$ of nuclease free water (Ambion, Thermo Fisher Scientific). Bloom (April 2015) and nonbloom (September 2016) RNA samples were further reverse transcribed with random hexamer primers 


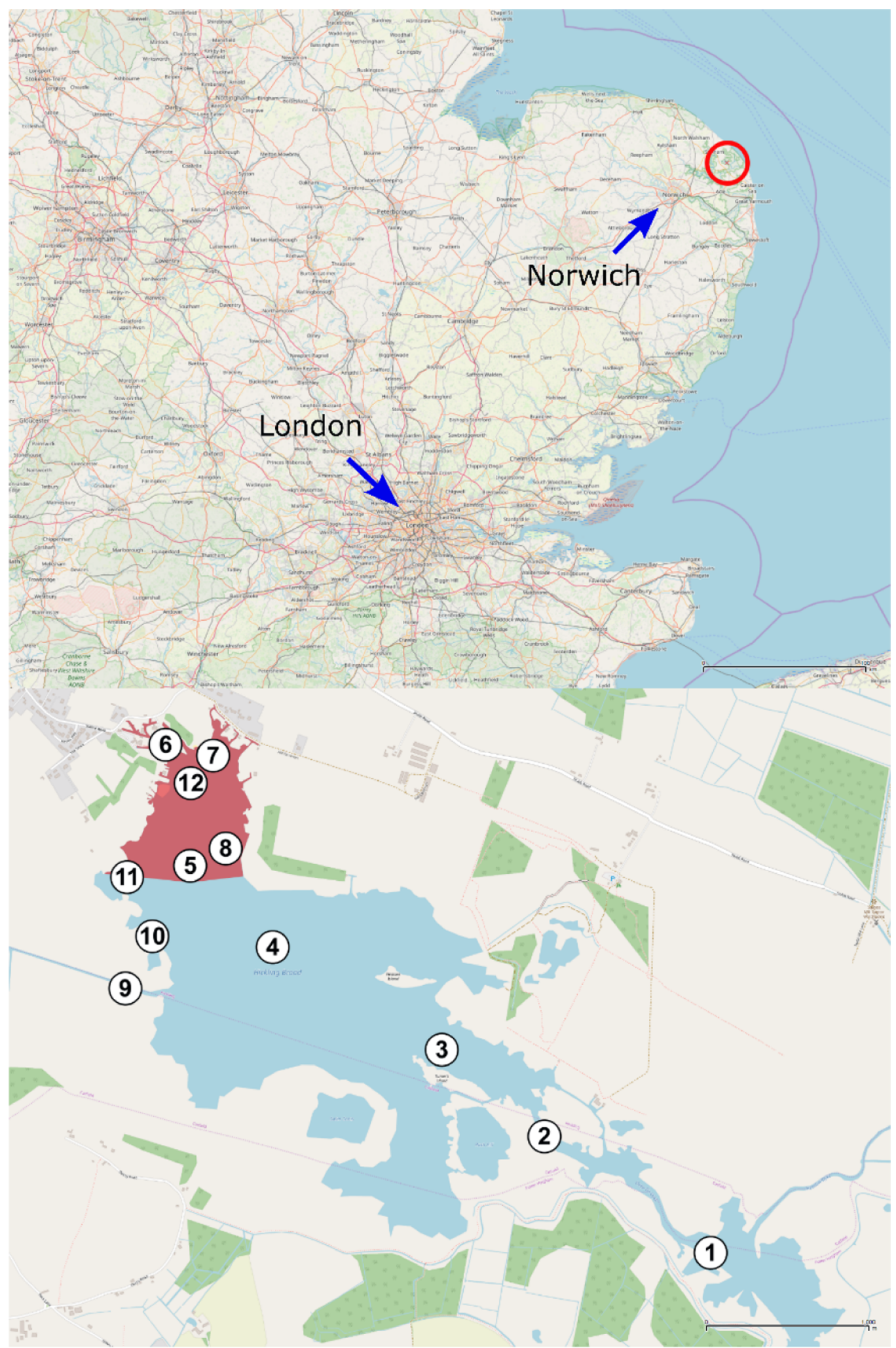

Figure 2. Map of wider Norfolk and sampling points on Hickling Broad. Top-map of the UK showing the location of Norwich relative to London (indicated by blue arrows). Hickling Broad is indicated with a red circle. Bottom-map showing the sampling points covering Hickling Broad established during the harmful P. parvum bloom in April 2015 and retained throughout the whole sampling campaign. The red shaded area represents the area where the majority of fish kills were observed during the bloom. Sample point 12 was added later as an additional sampling point and is not included in some analyses. Map was generated using QGIS with an OSM standard map. Scale bar (top) - $400 \mathrm{~km}$. Scale bar (bottom) - $1 \mathrm{~km}$.

(Invitrogen) and M-MLV reverse transcriptase (Promega) for

16S rRNA amplicon sequencing.
16S rRNA Gene Amplicon Sequencing for Water Samples. The pooled biological duplicates for DNA and cDNA samples from Hickling Broad water from bloom (April 
2015) and nonbloom (September 2016) samples, as well as the DNA samples from the hydrogen peroxide trial (June 2017) were selected for $16 \mathrm{~S} \mathrm{rRNA} / \mathrm{rDNA}$ amplicon sequencing. The primer set $515 \mathrm{~F} / 806 \mathrm{R}$ of the $\mathrm{V} 4$ variable region of the $16 \mathrm{~S}$ rRNA gene $^{25}$ was used for amplification. Amplification and amplicon sequencing were performed by MR DNA (Shallowater, TX, USA). Sequencing was performed on a MiSeq system according to manufacturer's instructions, obtaining between 106k and $257 \mathrm{k}$ reads per sample with an average length of $300 \mathrm{bp}$. Resulting data sets were analyzed by sequence analysis and phylogenetic classification using QIIME $1 .^{26}$

Specific qPCR for $P$. parvum and PpDNAV. The abundance of $P$. parvum internal transcribed spacer (ITS) copies in the water was quantified by qPCR using primers PrymF ${ }^{27}$ and PrymR- $3^{28}$ as previously described. ${ }^{28}$ The $25 \mu \mathrm{L}$ of the reaction mixture contained $12.5 \mu \mathrm{L}$ of SYBR Green JumpStart Taq ReadyMix (Merck), $0.15 \mu \mathrm{M}$ of each primer, $200 \mathrm{ng}$ of BSA mL $\mathrm{mL}^{-1}, 3.0 \mathrm{mM} \mathrm{MgCl}_{2}$, and $2.0 \mu \mathrm{L}$ of template DNA.

For the $P$. parvum virus PpDNAV, qPCR primers were designed to the major capsid protein 1 ( $m c p 1)$ gene of the PpDNAV isolate ${ }^{23}$ using the ARB software package ${ }^{29}$ based on the genome sequences recovered from the PpDNAV isolate. ${ }^{23}$ The resulting specific primer pair was named MCP1-1F (CCGTAATCCAGGTCTCGCTC) and MCP1-1R (CAAGGGAACTGACAGCCCAT) and amplified a 110 bp long fragment. The PpDNAV $m c p 1$ qPCR temperature profile consisted of an initial denaturation at $95{ }^{\circ} \mathrm{C}$ for $3 \mathrm{~min}$ and 35 cycles of denaturation, annealing, and extension at 95, 69.8, and $72{ }^{\circ} \mathrm{C}$ for 30,40 , and $40 \mathrm{~s}$, respectively, followed by a melting curve from 60 to $95{ }^{\circ} \mathrm{C}$ in $0.3{ }^{\circ} \mathrm{C}$ increments. The $25 \mu \mathrm{L}$ of the reaction mixture contained $12.5 \mu \mathrm{L}$ of SYBR Green JumpStart Taq ReadyMix (Merck), $0.3 \mu \mathrm{M}$ of each primer, $200 \mathrm{ng}$ of BSA $\mathrm{mL}^{-1}, 3.0 \mathrm{mM} \mathrm{MgCl}_{2}$, and $1.0 \mu \mathrm{L}$ of template DNA. The efficiency for this qPCR assay was 98\%. All assays were performed in a StepOnePlusTM Real-Time PCR System (Applied Biosystems) in triplicates, respective qPCR standards were used, and controls were run with water instead of DNA or cDNA extract.

Isolation of $\boldsymbol{P}$. parvum Hickling Strains. $P$. parvum strain HIK PR1A (clone 1A) and HIK PR6H (clone 6H) were isolated from Hickling Broad, Norfolk, UK $\left(52^{\circ} 44^{\prime} 48.3^{\prime \prime} \mathrm{N}\right.$, $\left.1^{\circ} 34^{\prime} 10.8^{\prime \prime} \mathrm{E}\right)$, during a minor bloom of $P$. parvum in June 2017. In brief, water from Hickling broad (50 mL) was inoculated into F/2 medium-Si $(100 \mathrm{~mL}, 5 \mathrm{PSU}) .{ }^{30}$ Several strains of $P$. parvum were isolated and made monoclonal by micropipetting single cells through rinses of sterile medium ${ }^{31}$ and plated into 96 -well plates. Isolates were allowed to grow for $2-3$ weeks at a constant temperature of $22{ }^{\circ} \mathrm{C}$ under a $12 / 12 \mathrm{~h}$ light/dark photoperiod with a constant photon flux of $120 \mu \mathrm{E}$ $\mathrm{m}^{-2} \mathrm{~s}^{-1}$ (QSL-100 Quantum Scalar Irradiance Meter, Biospherical Instruments, San Diego, USA) provided by Philips MASTER TL-D 58W/840 white tubes. Isolates from enriched cultures were further enriched by removing contaminating picoplankton by dilution. Enriched strains were transferred to 42-well plates and allowed to grow for approximately 2-3 weeks. Cultures were then made axenic by treatment with multiple rounds of antibiotics $\left(400 \mu \mathrm{g} \mathrm{mL}^{-1}\right.$ of streptomycin, 50 $\mu \mathrm{g} \mathrm{mL}^{-1}$ of chloramphenicol, $20 \mu \mathrm{g} \mathrm{mL}^{-1}$ of gentamicin, and $100 \mu \mathrm{g} \mathrm{mL}^{-1}$ of ampicillin). The absence of contaminating bacteria was confirmed by epifluorescence microscopy of culture samples stained with DAPI ${ }^{32}$ (Supporting Information, Figure 9). Genomic DNA of the Hickling Prymnesium strain was extracted from 10 cultures using phenol/chloroform and the $16 \mathrm{~S}$ bacterial rDNA sequence was amplified by PCR using primers 27F ( $5^{\prime}$-AGAGTTTGATCCTGGCTCAG-3') and 1492R (5' GGTTACCTTGTTACGACTT-3') (Supporting Information, Figure 10). ${ }^{55}$ 16S PCR products were cloned into pGEM-T easy vectors (Promega) and sent for DNA sequencing. This resulted in PCR products with $\sim 99 \%$ sequence similarity to the $16 \mathrm{~S}$ rDNA sequence of the plastid gene of $P$. parvum (Accession LN35251) (Supporting Information, Figure 11). The unsuccessful growth of any organism when inoculating aliquots of axenic cultures into different agar culture plates (MB, LB, YTSS, and R2A) also supported the cultures being free of bacteria (data not shown here). Clonal cultures were then carefully transferred and up-scaled to $75 \mathrm{~cm}^{2}$ cell culture flasks (Nunc EasyFLASK with Filter Caps, Thermo Fisher Scientific) containing $20-40 \mathrm{~mL}$ modified F/2 medium-Si. The growth of monoclonal strains was monitored every 3 days using a CASY cell counter (Innovatis, Reutlingen, Germany) to confirm that the cells were growing normally (Supporting Information, Figure 1). 3 strains were isolated in total, but HIK PR1A (clone 1A) and HIK PR6H (clone $6 \mathrm{H}$ ) were taken forward for studies due to their faster rate of growth.

Toxin Detection Using LC-MS. For the extraction and LC-MS-based analysis of prymnesins from cultured $P$. parvum HIK PR1A and HIK PR6H, the procedure outlined in the Supporting Information of Hems et al. was followed. ${ }^{14}$ For the extraction of prymnesins from natural water samples, $100 \mathrm{~mL}$ of water taken from locations 6 and 7 (Figure 2) was centrifuged at $3000 \mathrm{~g}$ to pellet cells and debris. The resulting supernatant was then filtered using a $0.45 \mu \mathrm{m}$ filter and next passed through a $1 \mathrm{~g}$ C18 cartridge (Sep Pak) at a flow rate of $1 \mathrm{~mL}^{-1}$ to load prymnesins. The cartridge containing the water-extracted prymnesins was then washed with 5 column volumes of water, before elution of toxins with 10 column volumes of $80 \% n$ propanol in water. For the extraction of prymnesins from fish gill plates taken from a dead pike (Exos Lucius) at the study site, the gill plates were first excised from the fish using a scalpel, before grinding the cells under liquid nitrogen using a pestle and mortar. At this point, the macerated material was extracted with cold acetone and prymnesins were isolated according to the protocol for P. parvum cells as described by Hems et al. ${ }^{14}$ The resulting dried samples after methanol and $n$-propanol extraction were resuspended in water and loaded onto, and eluted from, a $1 \mathrm{~g}$ of the $\mathrm{C} 18$ cartridge in the same manner as described above for the water extracted prymnesins.

The column eluates were then dried under vacuum using a rotary evaporator and resuspended in $2 \mathrm{~mL}$ of water. The samples were next "defatted" by adding EtOAc to a 1:1 ratio, shaken vigorously to ensure sufficient mixing of the phases, then allowed to sit and the aqueous and organic layers separated. The EtOAc layers were removed. This process was repeated a further three times, before the remaining aqueous fractions were again dried and re-suspended in $200 \mu \mathrm{L}$ of $0.1 \%$ TFA and subject to LC-MS analysis using an Acquity UPLC BEH C18 column as detailed in Hems et al. ${ }^{14}$

Hydrogen Peroxide Trial. A narrow dyke close to location 6 (Whispering Reeds Boatyard back lagoon, approx. volume 730 $\mathrm{m}^{3}$ ) was chosen as the field trial site for hydrogen peroxide application as it was easily accessible from the bank side and it was the site where thousands of fish congregated during the toxic bloom in April 2015. Preliminary laboratory studies identified that a concentration of $40 \mathrm{mg} / \mathrm{L}$ of $\mathrm{H}_{2} \mathrm{O}_{2}$ was sufficient to reduce late-logarithmic phase $\left(\sim 3,000,000\right.$ cells $\left.\mathrm{mL}^{-1}\right) P$. parvum 


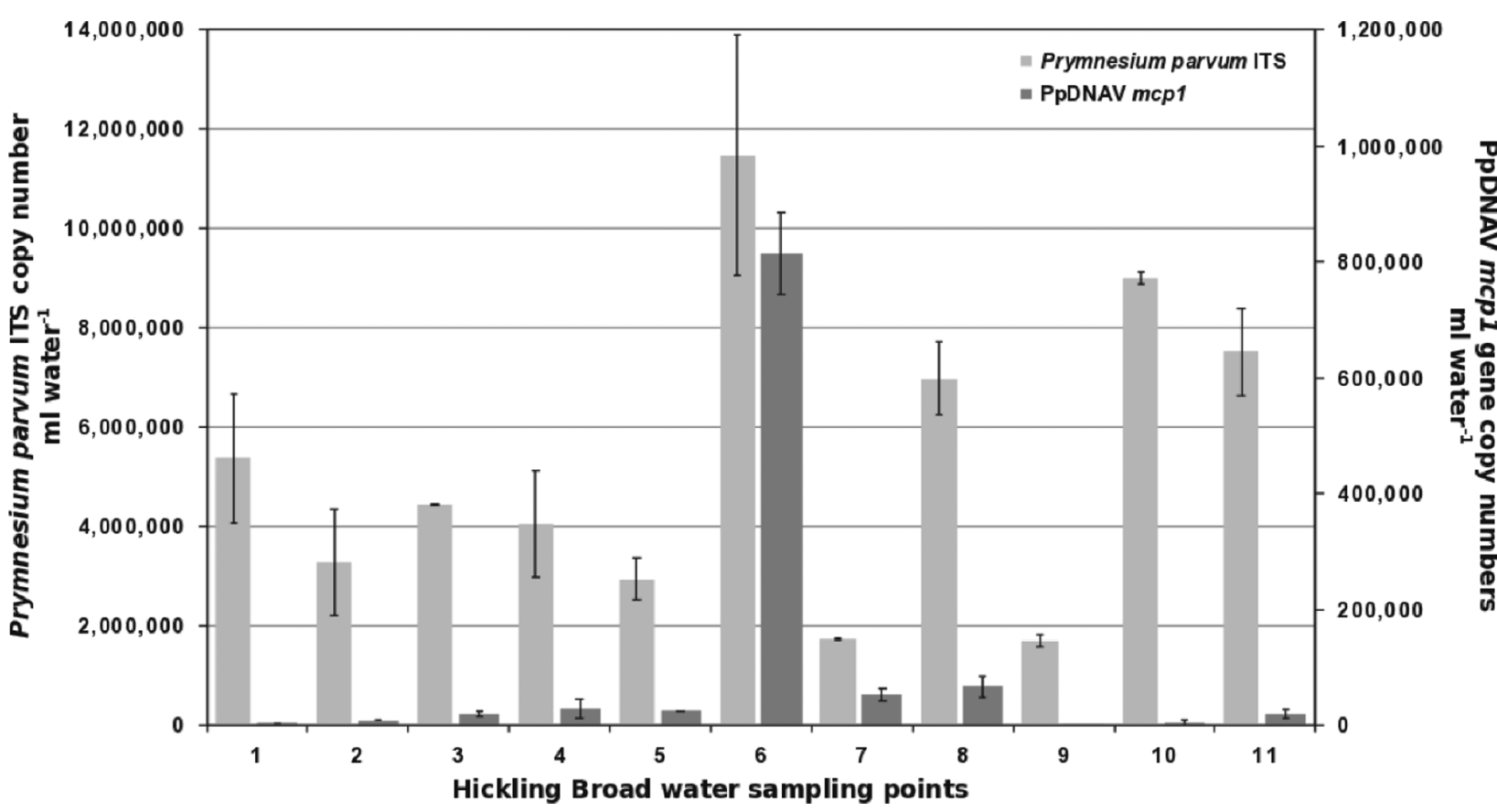

Figure 3. Abundance of P. parvum and PpDNAV in Hickling Broad water samples during the harmful bloom in April 2015. Abundance of P. parvum specific ITS genes (light gray bars) and PpDNAV mcpl genes (dark gray bars) was measured by qPCR of total DNA extracted from Hickling Broad water samples collected during the harmful P. parvum bloom in April 2015. Values represent the average of three replicates with their respective standard deviations. Numbers refer to sampling sites on Hickling Broad (see Figure 1).

populations by $>97 \%$ over a $72 \mathrm{~h}$ time period (Supporting Information, Figure 7). The target concentration of hydrogen peroxide $(40-50 \mathrm{mg} / \mathrm{L})$ was achieved by the application of hydrogen peroxide stock $(35 \mathrm{w} / \mathrm{w} \%)$ using two bank fixed jets (Oxyjet 50) (Supporting Information, Figure 8). To ensure efficient mixing, a water aerator unit, set up in the center of the dyke, was employed. The concentration of hydrogen peroxide was monitored using Quantofix test strips (Peroxide 100, Sigma Aldrich, UK). The target concentration was maintained for up to $3 \mathrm{~h}$ after application. Five sampling locations were chosen; three within the dyke directly adjacent to the area being treated with $\mathrm{H}_{2} \mathrm{O}_{2}$, and two negative controls outside of the dyke (see Figure $7 \mathrm{a})$. Water samples were collected from all sampling points before (T0) and 1, 4, 6, 24, 96, and $456 \mathrm{~h}$ after hydrogen peroxide application. The water samples were used for nucleic acid extraction and for qPCR and 16S rRNA gene amplicon sequencing as described above. For each sample, $\mathrm{pH}$, temperature, and conductivity measurements were taken.

\section{RESULTS}

Study Site-Hickling Broad. A toxic bloom of $P$. parvum on Hickling Broad, Norfolk, England, was first reported by members of the public on 13th March 2015 when multiple fish mortalities were observed. Subsequently, the site was visited on 17th March 2015 and water samples were taken from 12 locations across the broad for further analysis (Figure 2). Fish mortalities noted included: Common Bream (Abramis brama), Common Roach (Rutilis rutilis), Common Rudd (Scardinius erythrophthalmus), European Perch (Perca fluviatilis), Northern Pike (Esox lucius), and few cases of Tench (Tinca tinca).

Quantification of $P$. parvum and PpDNAV in Water Samples from a Toxic Bloom. Total DNA extracted from water samples taken during the toxic bloom of 2015 was analyzed by qPCR for the marker genes of both $P$. parvum and its lytic virus, PpDNAV. ${ }^{23}$ A technical triplicate of results suggested a severe bloom of $P$. parvum was ongoing, with copy numbers of the ITS region of $P$. parvum DNA reaching almost $12 \times 10^{6}$ copies $\mathrm{mL}^{-1}$ of water at location 6 . This represented an, on average, 1000-1500 times higher number than seen in nonbloom conditions, as discussed later. In general, $P$. parvum was seen in a higher abundance at sampling locations toward the most northerly point of the Broad (Figure 3), particularly location 6 , which fell within a very shallow, sandy dyke near to a waterside restaurant and pleasure craft boatyard. Location 7 was an exception to this trend, but the sighting of severe cases of what appeared to be fungi (Supporting Information, Figure 2) near this location were noted as a potential reason for the lack of $P$. parvum observed at this location.

We recently showed that $P$. parvum can be infected by a lytic virus, $\mathrm{PpDNAV}{ }^{23}$ which was isolated from this location. Thus, we next sought to determine whether the bloom of P. parvum in 2015 was infected by PpDNAV. Using the same DNA samples obtained from the water samples taken during the bloom, we performed qPCR with primers designed to specifically amplify the major capsid protein ( $m c p 1)$ gene of PpDNAV. Results from these qPCR experiments showed 12-1000 times higher copy numbers of $m c p 1$ at location 6 compared to the other sampling locations, suggesting active infection was occurring at this location during our sampling regime (Figure 3). Levels of $m c p 1$ at other sampling locations remained lower or in some cases undetectable, suggesting that the populations of $P$. parvum at these locations were not infected by PpDNAV. High levels of algal ITS reads did not correlate directly with fish deaths, which required both high levels of algal ITS reads and viral $m c p 1$ reads. For example, sampling locations 10 and 11 showed higher algal ITS reads than most other sampling locations but very few PpDNAV $m c p 1$ reads and few/no observable fish deaths nearby. Conversely, location 6 showed high algal ITS reads and high PpDNAV1 mcpl reads with many observable fish mortalities and distressed fish (Supporting Information, Figure 3). 


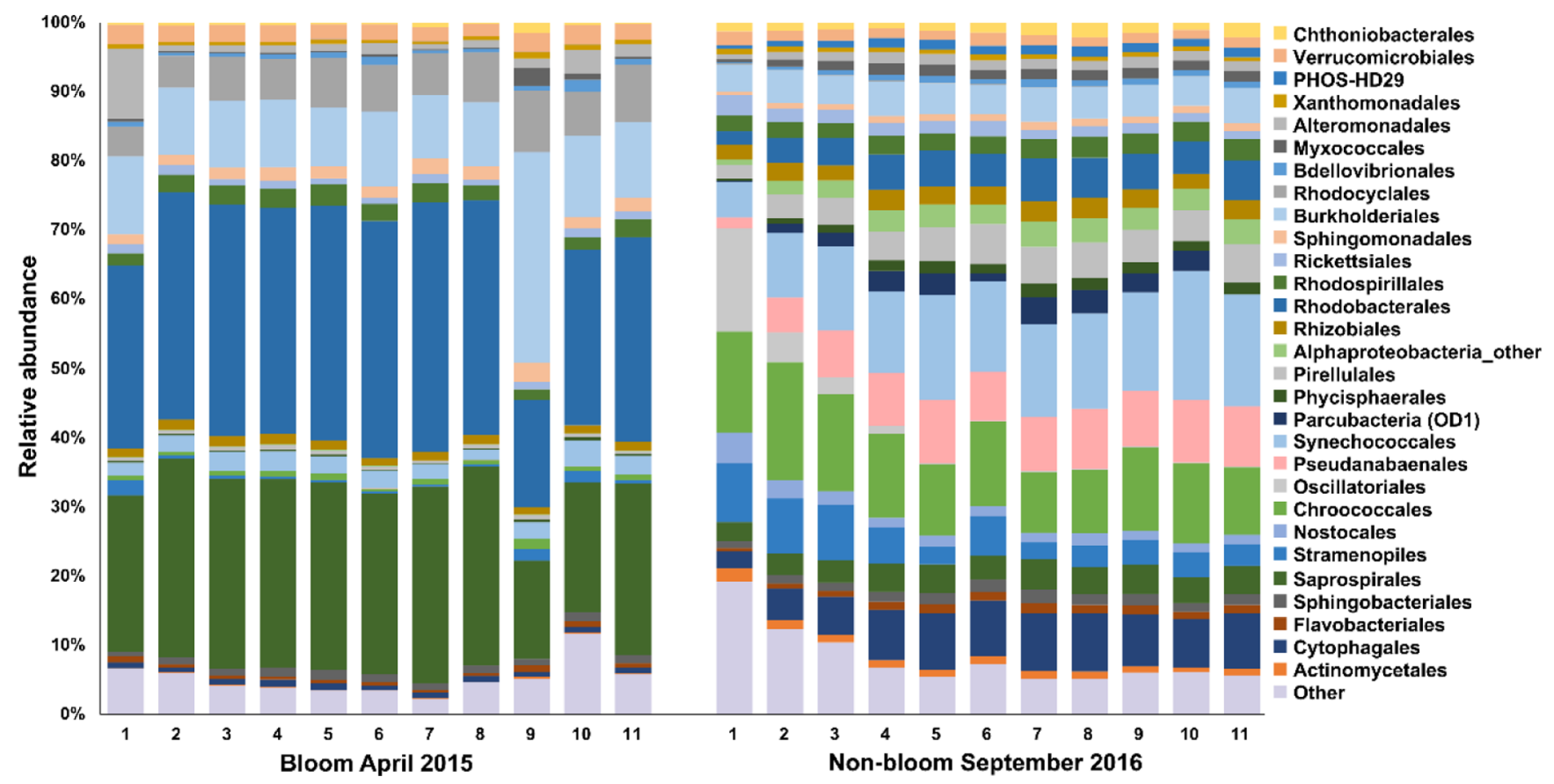

Figure 4. Microbial community profiles of the harmful P. parvum bloom compared to nonbloom water on Hickling Broad, obtained by $16 \mathrm{~S}$ rRNA gene amplicon sequencing, excluding chloroplast sequences. Profiles are derived from total DNA extracted from pooled duplicate Hickling Broad water samples collected at consistent sampling points during the harmful P. parvum bloom in April 2015 and during a nonbloom phase in September 2016. Relative abundance of taxonomic groups within each sample is shown at the order level as percentages. Only taxa with a combined relative abundance of $\geq 0.1 \%$ are shown. Numbers refer to sampling sites on Hickling Broad (see Figure 1).

Community Composition during a Bloom Compared to Nonbloom Conditions. To investigate the effect of the $P$. parvum bloom on the microbial ecosystem, we performed $16 \mathrm{~S}$ rRNA gene microbial community analysis during the bloom and during nonbloom conditions (Figure 4).

Interestingly, the bloom of $P$. parvum coincided with the elevated levels of Rhodobacterales, specifically Marivita (up to $36 \%$ abundance) compared to nonbloom conditions (6\%). This was also observed for Saprospirales, specifically Lewinella (up to $29 \%$ bloom vs $4 \%$ nonbloom), and Rhodocyclales, specifically Methyloversatilis (up to $9 \%$ bloom vs $0.8 \%$ ). Conversely, during nonbloom conditions cyanobacterial genera, such as Microcystis (up to $0.8 \%$ bloom vs $12.4 \%$ nonbloom), Cytophaga (up to $0.63 \%$ bloom vs $7.5 \%$ nonbloom), and Synechococcus (up to $2.2 \%$ bloom vs $16.5 \%$ nonbloom), were more abundant, in an overall more diverse microbial community. The same community pattern observed in the DNA samples could be observed in the cDNA $16 \mathrm{~S}$ rRNA profiles (Supporting Information, Figure 4), indicating no significant differences between present and active microorganisms in the water samples during bloom and nonbloom.

Results including $P$. parvum chloroplast $16 \mathrm{~S}$ rRNA genes showed that during the bloom $P$. parvum chloroplast $16 \mathrm{~S}$ rRNA genes dominated the ecosystem in all sampling locations examined, representing between 20 and $41 \%$ of the total microbial community in location 9 (Supporting Information, Figure 5). During nonbloom conditions, levels of $P$. parvum were as low as only $2 \%$ of the total population. For other eukaryotic phytoplankton, the only phyla that could be detected in the bloom and nonbloom 16S data sets were Chlorophyta and Cryptophyta; however, their abundances were $<0.1 \%$ per sample.

Detection of Prymnesins in Environmental Water Samples and Fish Gill Cells. We next sought to detect the prymnesin toxins from environmental water samples. Although they are implicated in fish mortality worldwide and have previously been extracted and detected from laboratory-grown cultures of $P$. parvum, the prymnesins have yet to be detected from environmental water samples or from their speculated targets (gill cells of fish). Samples were taken from locations 6 and 7 due to the significant volume of fish deaths at these locations. We therefore applied a modified version of the extraction method of Manning and La Claire ${ }^{33}$ For the extraction of prymnesins from gill plates, a dead pike (Exos lucius) was recovered from the toxic bloom and the gill plates were excised from the fish, macerated with a pestle and mortar, and extracted using a combination of solvent extraction and solid-phase extraction, according to Manning and La Claire ${ }^{33}$ Both samples were then analyzed using LC-MS, as previously described. ${ }^{14}$ No signals corresponding to prymnesin-1 or prymnesin-2 were detected for either water or gill-extracted samples. Upon further examination, masses corresponding to the aglycone backbone of prymnesin- $\mathrm{B} 1$, recently discovered by Rasmussen et al., ${ }^{13}$ could be tentatively detected (Figure 5). Extracted-ion chromatograms suggested that the B-type prymnesins were present in the gills of a dead pike and from a water sample taken at location 6 (Figure 5A). A high background prevented the detection of these compounds from a water sample taken at location 7. This agrees with the findings of higher levels of $P$. parvum at location 6 during the bloom, as reported above.

Detection of Prymnesins from Strains of $P$. parvum Isolated from the Study Site. Due to the low sample availability and the evidently low concentrations of the suspected toxins present in natural samples, we next sought to isolate a strain of $P$. parvum from Hickling Broad and extract toxins from dense cultures of laboratory-grown algae to unambiguously confirm their identity. P. parvum was isolated 


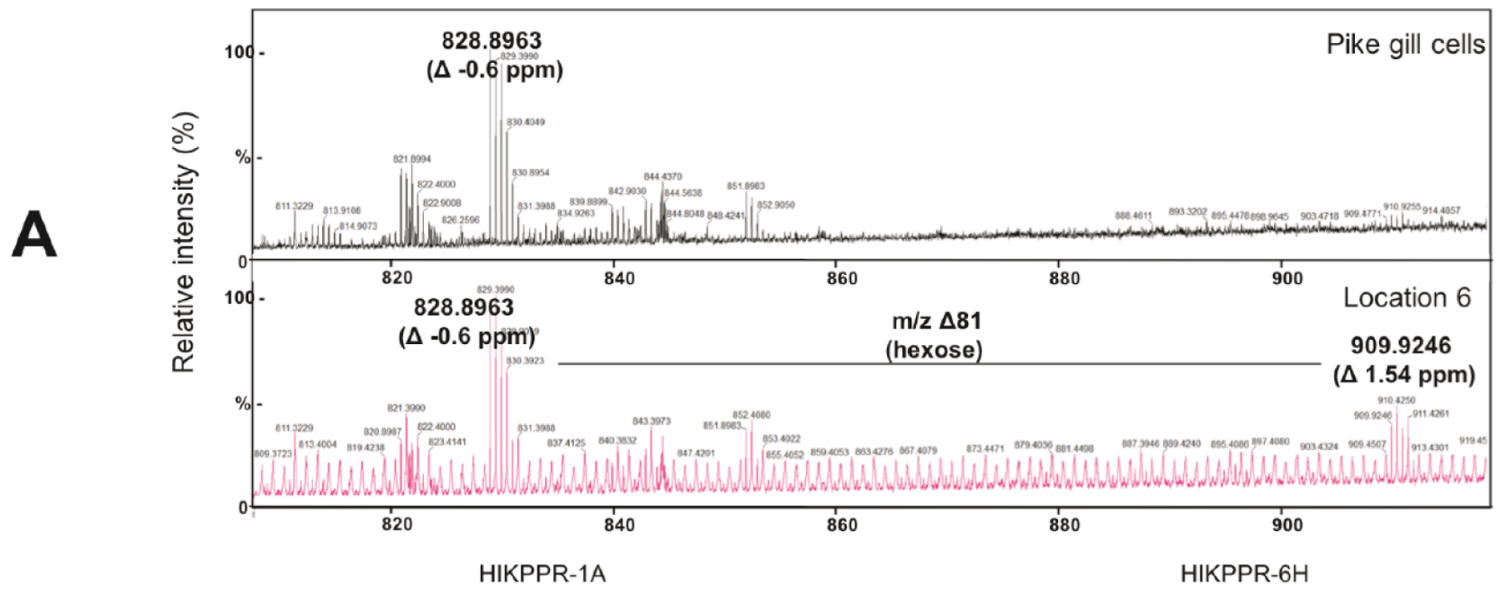

B
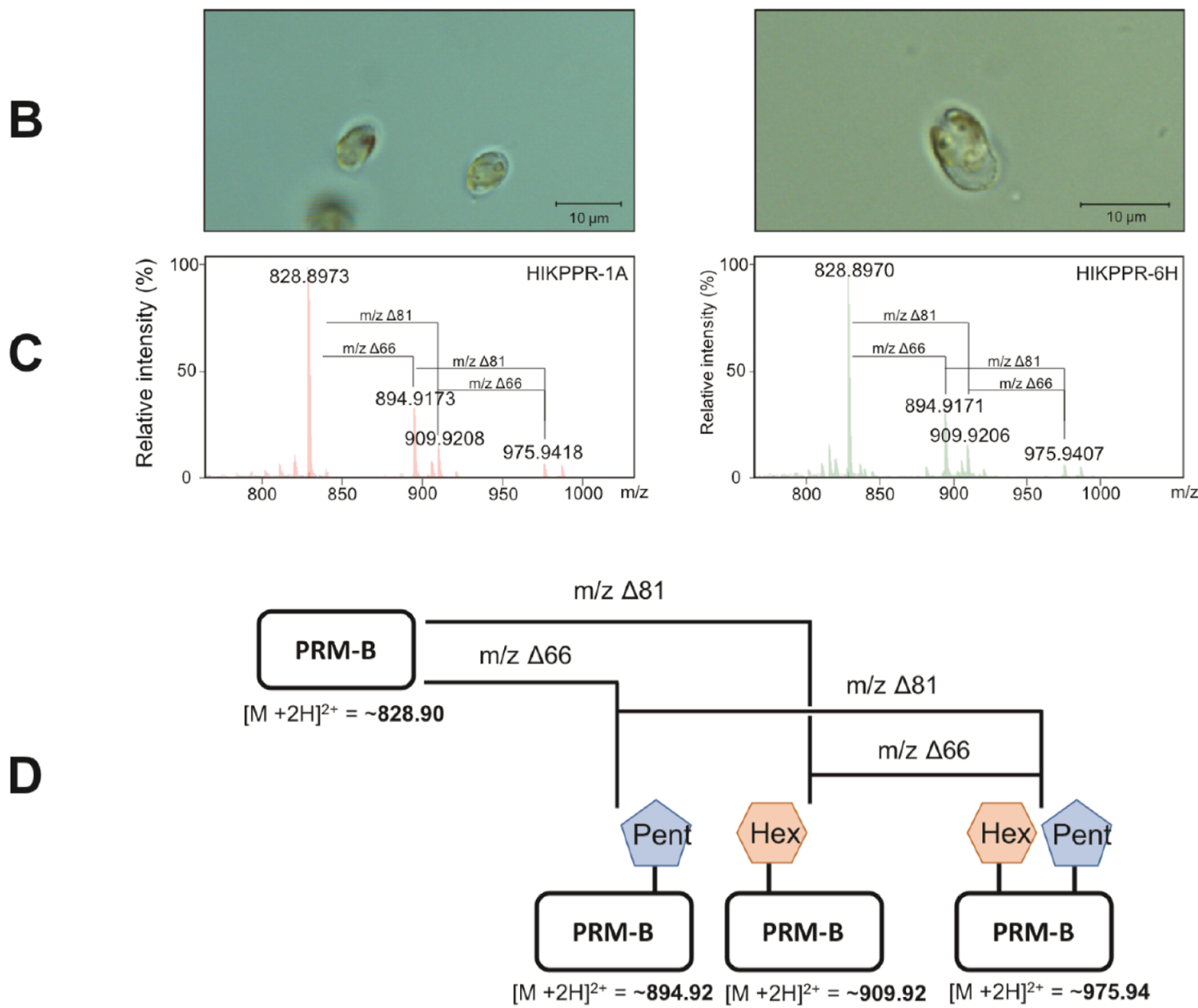

Figure 5. MS-based identification of B-type prymnesins from the environmental samples and isolates of $P$. parvum from Hickling Broad. (A) ESI-MS spectrum showing the detection of the diagnostic signal $(\mathrm{m} / z$ 828.8963, $\Delta-0.6 \mathrm{ppm})$ for the backbone of the B-type prymnesins from pike gill cells (top), and water sample 6 (bottom) taken during a toxic bloom. ESI-MS signal corresponding to the singly glycosylated form of the toxin $(\mathrm{m} / z$ 909.9246, $\Delta 1.54 \mathrm{ppm}$ ) could also be seen in the water sample from location 6. (B) Light microscopy images of P. parvum HIK PR1A (left) and HIK PR6H (right). (C) ESI-MS spectra showing the detection of the diagnostic signals for the aglycone $(\mathrm{m} / z \sim 828.9)$, mono glycosylated with a pentose $(m / z \sim 894.9)$, mono glycosylated with a hexose $(m / z \sim 909.9)$, and double glycosylated with pentose and hexose $(m / z \sim 975.9)$ forms of the B-type prymnesins, from HIK PR1A (left) and HIK PR6H (right). All masses observed for the toxins have errors less than $\Delta 3 \mathrm{ppm}$ with the exception of $m / z$ 975.9407 of the intact double glycosylated toxin from HIKPPR-6H, which has an error of $\Delta-3.8 \mathrm{ppm}$. (D) Schematic of the proposed prymnesin-B fragmentation events observed in ESI-MS spectra (A,C). Losses of $m / z=66$ or $m / z=81$ correspond to the loss of pentose or hexose units from the toxin backbone, respectively.

and made axenic by a combination of single-cell micropipetting and antibiotic treatments, ${ }^{31}$ which resulted in two strains of $P$. parvum, HIK PR1A, and HIK PR6H (Figure 5B), which were then both examined for their production of prymnesin toxins. Cultures of both strains were grown to late logarithmic phase, harvested, and their prymnesins extracted as previously 

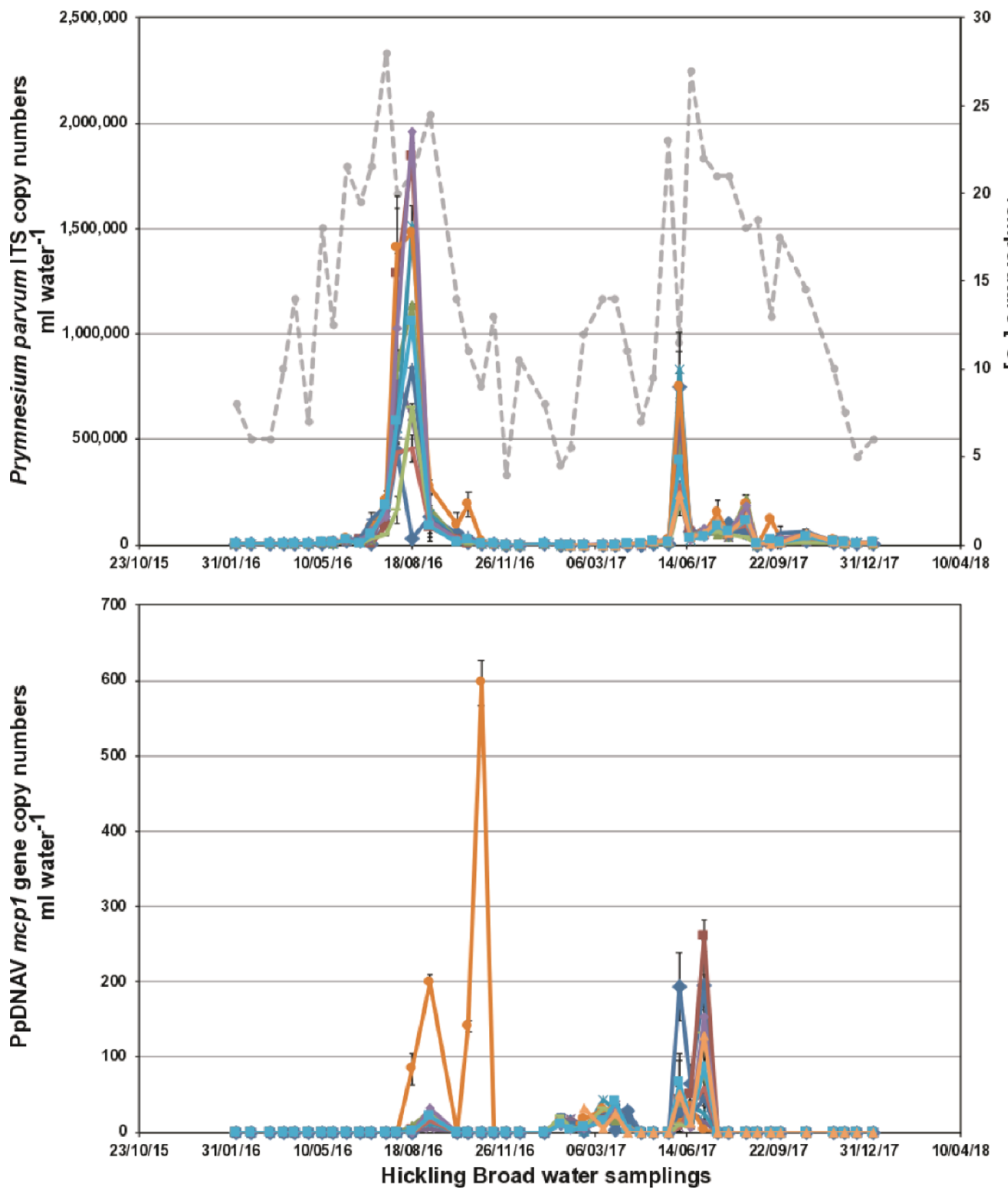

- - temper ature

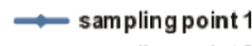

- sampling point 2 - sampling point 3

$\because$ sampling point 4

- sampling point 5 _ sampling point 6 _ sampling point 7 sampling point 8 sampling point 9

$\longrightarrow$ sampling point 10 - sampling point 11 _ sampling point 12

Figure 6. 2 year survey of P. parvum and PpDNAV population dynamics on Hickling Broad. Abundance of P. parvum specific ITS genes and PpDNAV mcp1 genes was measured by qPCR of total DNA extracted from Hickling Broad water samples collected at consistent sampling points every $2-4$ weeks from January 2016 to January 2018 (see Figure 2). Values represent the average of three replicates with their respective standard deviations.

described. ${ }^{14}$ Both strains gave similar toxin profiles and were confirmed to produce the B-type prymnesins, as expected (Figure 5C). Although the standards for prymnesin toxins were not available, the prymnesins behaved similarly to prymnesins extracted from commercial strains of $P$. parvum with respect to column retention times and isotope patterns. In addition to detecting signals corresponding to prymnesin-B1 that contains 1 hexose sugar, we were also able to detect $\mathrm{m} / \mathrm{z}$ signals corresponding to the same toxin backbone but glycosylated with a pentose sugar (prymnesin-B2 $2^{13}$ ), and the toxin with both a hexose and pentose which Rasmussen et al. detected in $P$. parvum strains from Denmark, Norway, and Australia ${ }^{13}$ (Figure 5B). Due to a low separation of these species under our chromatography conditions (Supporting Information, Figure 6 ), it is unclear whether the organism produces a mixture of these forms of the toxin (Figure 5D), or whether the loss of $\mathrm{m} / z$ values corresponding to these sugars is an artefact of mass spectrometry fragmentation, as is frequently the case for this class of compounds. ${ }^{13,14,33}$

Seasonal Dynamics of $P$. parvum and PpDNAV over a 2 Year Period. Using qPCR, we next sought to follow seasonal populations of $P$. parvum on Hickling Broad and to determine whether blooms are regulated/controlled by viral infections of $P$. parvum with PpDNAV. Water samples were taken bimonthly over a 2 year period and total DNA was extracted and subjected to qPCR using the previously described P. parvum (ITS) and 


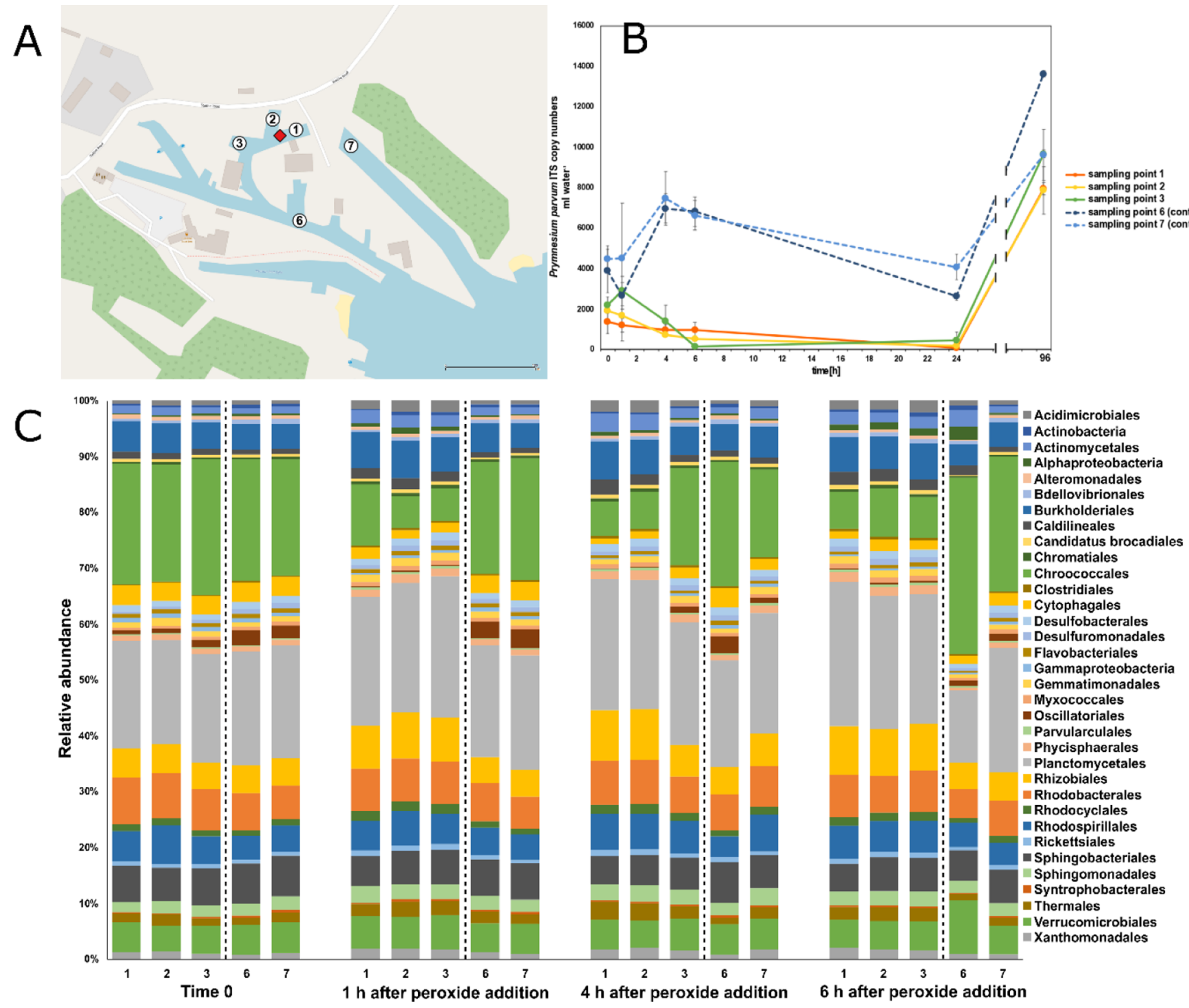

Figure 7. Effect of peroxide treatment on the abundance of $P$. parvum and microbial community profiles in Hickling Broad water samples. (A) Study site on Hickling Broad where hydrogen peroxide was applied (locations 1-3), and control locations outside of the dyke (locations 6, 7). Scale bar represents $100 \mathrm{~m}$. (B) Abundance of P. parvum specific ITS gene was measured by qPCR of total DNA extracted from Hickling Broad water samples collected over a time series before (T0) and after in situ peroxide treatment $(1,4,6,24$, and $96 \mathrm{~h})$ in June 2017. Values represent the average of three replicates with their respective standard deviations. (C) Microbial community profiles derived from the total DNA extracted from Hickling Broad water samples collected over a time series before (T0) and after in situ peroxide treatment $(1,4$, and $6 \mathrm{~h})$ in June 2017. Relative abundance of taxonomic groups within each sample is shown at the order level as percentages. Only taxa with a combined relative abundance of $>0.1 \%$ are shown. Numbers refer to sampling sites during the peroxide trial, with dashed lines dividing treatment sites (sites 1,2, and 3 ) from control sites (sites 6 and 7 ).

PpDNAV $(m c p 1)$ primers. These data showed that the abundance of $P$. parvum and PpDNAV positively correlated with air/water temperature, which is known to affect the frequency and severity of Prymnesium blooms ${ }^{7,34}$ (Figure 6). For levels of $P$. parvum, the sampling sites displayed a similar seasonal trend, but location 6 consistently showed higher $P$. parvum numbers than the average for the whole Broad, agreeing with previous data for the toxic bloom of 2015. Furthermore, the 2 year time course showed that blooms of $P$. parvum strongly correlate with an increase in temperature, where the major 2 blooms of the study both occurred in the warmer months of August 2016 and June 2017 when the temperature was higher $\left(21{ }^{\circ} \mathrm{C}\right.$ for August 2016 and $27{ }^{\circ} \mathrm{C}$ for June 2017). Smaller blooms of $P$. parvum were observed throughout the later summer months and leading into Autumn (August to October) but levels of $P$. parvum remained low consistently throughout winter and spring (November to May), where temperatures were at their lowest. In addition to temperature, salinity, and $\mathrm{pH}$ were also measured throughout the monitoring period at each sampling trip. The Hickling Broad salinity exhibited some seasonality across all sampling sites, with $3.3 \pm 0.5$ psu in summer and $5.52 \pm 0.68 \mathrm{psu}$ in winter. The $\mathrm{pH}$ also showed a slight seasonality of $\mathrm{pH} 8.9 \pm 0.31$ in summer to $\mathrm{pH} 7.95 \pm 0.34$ in winter across all sampling sites. It is important to note that no fish kills were recorded throughout this 2 year time course, despite the blooms of P. parvum.

Copy numbers for PpDNAV mcpl displayed a similar trend but appeared to reach the highest values shortly after $P$. parvum ITS values reached their highs, during a crash of the algal populations. The first bloom of $P$. parvum reached its peak on 18th August 2016, which was followed by a peak of PpDNAV 3 weeks after on 6th September 2016. A subsequent smaller bloom 
of $P$. parvum was observed at location 6 on 18th October 2016, and this was again followed by a sharp rise in PpDNAV levels shortly after on 1st November 2016. This pattern was also seen for the major bloom of $P$. parvum in 2017 on 6th June where viral transcripts saw a sharp peak on the same date, and also shortly after the algal bloom on 3rd July 2017. Interestingly, viral numbers saw a small, prolonged rise throughout the early months of 2017 (January to April) while values for P. parvum during this time remained very low. The opposite was also observed in 2017 after the major bloom of $P$. parvum had occurred; smaller blooms of $P$. parvum were noted with no observed rise in viral numbers during this period.

Mitigation of $P$. parvum Blooms with Hydrogen Peroxide and Its Impact on Microbial Community Composition. The Norfolk Broads are a National Park and as such the use of chemical algaecides are not permitted. However, the Environment Agency that has the responsibility of managing the Broads already use dilute hydrogen peroxide for the aeration of hypoxic water; a chemical that, at higher concentrations, has previously been shown to reduce levels of cyanobacteria, $^{35}$ toxic phytoplankton, ${ }^{36}$ and even their corresponding toxic metabolites. ${ }^{36}$ Hypoxic waters are not uncommon on the Norfolk Broads and could be a result of agricultural runoff from the surrounding arable land causing eutrophication events. We therefore set about determining whether low doses of hydrogen peroxide could be an effective treatment method for the blooms of P. parvum. Following approval from the Norfolk Wildlife Trust, hydrogen peroxide dosing trials were carried out in June 2017, close to location 6 (Figure 2), in a small dyke, where fish were seen to congregate during the toxic bloom of 2015 (Figure 7A). Hydrogen peroxide was applied, and concentrations were raised to the target 40-50 $\mathrm{mg} / \mathrm{L}$ (Figure $7 \mathrm{~A}$ - red square). In total, $3 \times 30 \mathrm{~L}$ drums of 35 w/w \% hydrogen peroxide were used, at a cost of $£ 204$ each (excl. UK VAT). Water samples were taken regularly at 3 locations close to the site of $\mathrm{H}_{2} \mathrm{O}_{2}$ application (locations 1,2,3), and 2 further sites outside of the dyke that would act as negative controls (locations 6 and 7). Water samples taken from these locations were extracted for cellular DNA and a combination of qPCR analysis (Figure 7B), and $16 \mathrm{~S}$ community profiling (Figure 7C) was carried out to assess the impact of $\mathrm{H}_{2} \mathrm{O}_{2}$ dosing on $P$. parvum levels and the overall balance of the microbial community. qPCR analysis using primers designed to amplify the ITS region of $P$. parvum showed that before treatment levels of $P$. parvum were considerably lower than in bloom conditions (200-500 copies $\mathrm{mL}^{-1} v$ s highs of $12,000,000$ copies $\left.\mathrm{mL}^{-1}\right) . P$. parvum ITS reads started to fall immediately after dosing with hydrogen peroxide (Figure 7B). These low levels remained low in locations 1,2 , and 3 , relative to the control locations (6 and 7) over the subsequent $24 \mathrm{~h}$. Levels of $P$. parvum at the treatment site were seen to recover to normal levels relative to the control locations $96 \mathrm{~h}$ after $\mathrm{H}_{2} \mathrm{O}_{2}$ treatment, suggesting no adverse prolonged effects on the local P. parvum population in this open water system.

$16 \mathrm{~S}$ rRNA gene amplicon sequencing was carried out to look at the overall effect of hydrogen peroxide treatment on the microbial community (Figure $7 \mathrm{C}$ ). Before treatment, little differences in the relative percentage abundance of taxonomic groups between sampling locations was observed. However, $1 \mathrm{~h}$ after $\mathrm{H}_{2} \mathrm{O}_{2}$ treatment, noticeable changes could be observed in the relative abundances of taxonomic groups between the treated locations $(1,2$, and 3 ) versus control locations (6 and 7). The largest noticeable effect was on the relative abundance of
Chroococcales (largest green bars), which dropped from $24 \%$ abundance in location 3 to $5 \%$ relative abundance just $1 \mathrm{~h}$ after peroxide treatment.

\section{DISCUSSION}

P. parvum causes $\mathrm{HABs}$ in both inland and coastal waters, leading to devastating fish kills with extensive economic and ecological impacts. P. parvum has plagued the Norfolk Broads, for example, with toxic blooms for over a century, damaging the ecosystem and the local economy of the otherwise thriving National Park. ${ }^{20}$ Although reports suggest that toxic blooms of $P$. parvum are slowing down on the Norfolk Broads, 12 major fish kills, resulting in thousands of fish mortalities have been reported since the 1980s. ${ }^{37}$ Despite the significance of these $P$. parvum blooms, the bloom dynamics, microbiome of $P$. parvum blooms, and the toxicity mechanisms resulting in fish mortalities are still poorly understood. In this study, we took a multidisciplinary approach to learn more about bloom dynamics and the bloom microbiome of this harmful alga and its lytic virus, PpDNAV, and provide potential solutions and future management strategies for blooms of this organism.

A toxic bloom of $P$. parvum on Hickling Broad was first reported on 13th March 2015 and ultimately resulted in thousands of fish deaths, with an estimated 600,000 fish manually relocated to safer waters over the course of the toxic episode. The inspection of the extent of the bloom and water sampling was subsequently carried out on 17th March 2015, where it was noted that the epicenter of the bloom was close to location 6 at the most northerly point of the Broad (Figure 2 and Supporting Information ,Figure 3). Initial qPCR experiments used to quantify the extent of the $P$. parvum bloom showed elevated transcript levels of $P$. parvum ITS gene and PpDNAV $m c p 1$ across the broad, but particularly in location 6, where numbers for $P$. parvum ITS surpassed 11,000,000 copies $\mathrm{mL}^{-1}$ water (Figure 3 ), agreeing with the observations of increased fish mortalities at Location 6. The locations of fish deaths across the broad appeared to correlate with both increased algal ITS reads and PpDNAV mcpl reads. It is therefore tempting to speculate that the viral presence, or P. parvum bloom demise as a result of viral infection, is required for bloom ichthyotoxicity: this idea warrants further study. Taking an average of ITS2 copies for $P$. parvum KAC 39 (10.0 \pm 2.8 copies per cell), $P$. parvum CCMP 708 (15.6 \pm 1.6 copies per cell), and P. parvum Texoma $(11.7 \pm$ 0.6 copies per cell) from previous works, ${ }^{28,38}$ we can predict that the peak of the Hickling bloom reached cell densities in the range of 900,000 cells $\mathrm{mL}^{-1}$ at Location 6. For comparison, previous reports of severe $P$. parvum blooms have shown cell densities between 100,000 and 200,000 cells $\mathrm{mL}^{-1}$. $^{39}$ However, strain variability and the haplo-diploid life cycle of haptophytes means the quantification of cell numbers based on ITS2 copies should be taken with pre-caution. ${ }^{6} 16 \mathrm{~S}$ rRNA gene profiling showed distinct microbial communities under P. parvum bloom and nonbloom conditions, with the nonbloom conditions exhibiting a higher diversity of abundant taxonomic groups. This effect has been shown previously with laboratory microcosms as well as environmental $P$. parvum blooms, resulting in changed microbial community compositions and decreased diversity during some blooms. ${ }^{40,41}$ Some of the microorganisms showing the highest relative abundances in the bloom microbial community have been described as versatile methylotrophs (Methyloversatilis) or complex carbohydrate degraders (Lewinella), and so might benefit from the increased cell biomass being made available during the bloom. ${ }^{53,54}$ 
Marivita species have further been shown to co-occur with a wide range of algae and have therefore been postulated to be growth-promoting algal symbionts. ${ }^{42}$ Similar connections have been reported before, network analyses of environmental $P$. parvum were positively correlated with several bacterial orders, including the Rhodobacterales and Rhodocyclales ${ }^{43}$ and laboratory microcosms of $P$. parvum blooms also highlighted Rhodobacterales as an indicator species. ${ }^{41}$ Cyanobacterial groups, such as Microcystis, Cytophaga, and Synechococcus, seem to be suppressed or outcompeted during blooms of $P$. parvum compared to nonbloom conditions, ${ }^{44}$ although other factors not considered in this study, including nutrient composition and seasonality, may be the reason for these differences. $^{40,43}$

Even though many metabolites produced by $P$. parvum have been implicated in fish mortality, ${ }^{45,46}$ more research is being conducted on the polyether prymnesins due to their potent ichthyotoxicity. ${ }^{8,11}$ Although these toxins have been well described and detected in laboratory settings, before this study they had never been detected in environmental samples, leading to speculation about whether they are ecologically relevant to fish deaths. Furthermore, some research suggests toxic prymnesins are mainly cellular/membrane-bound, ${ }^{47}$ while others appear to show that the prymnesins are predominantly found in cell-free supernatants. ${ }^{48}$ In this study, we used LC-MS methods to confirm the presence of the recently discovered prymnesin-B $1^{13}$ from both, cell-free, environmental water samples as well as gill cell extracts of a deceased pike taken during the Hickling Broad toxic bloom of 2015 (Figure 5A). Given the reported $\mathrm{EC}_{50}$ value of $5.98 \pm 0.65 \mathrm{nM}$ for prymnesin$\mathrm{B} 1,{ }^{13}$ it is possible that as little as $1 \mu \mathrm{g}$ of prymnesin-B1 being present in the $100 \mathrm{~mL}$ of the environmental water sample was enough to cause fish mortality, explaining the large signal to noise seen in Figure 5A. To unambiguously confirm the toxin identity and to show that it was produced by $P$. parvum, we isolated $P$. parvum from the study site. Using single-cell micropipetting, we were able to isolate two strains, HIKPPR$1 \mathrm{~A}$ and HIKPPR-6H (Figure 5B), and show, using previously described methods, ${ }^{14}$ that both strains produce B-type prymnesins (Figure 5C). Interestingly, both strains appear to produce a doubly glycosylated form of the B-type prymnesins ${ }^{13}$ (Figure 5D). Taken together, the combined detection of these toxins in environmental samples, as well as the confirmation that these same toxins are produced in a laboratory setting by $P$. parvum HIKPPR-1A and HIKPPR-6H isolated from the study site, adds claim to the argument that the prymnesins are ecologically relevant to fish mortalities, although further experiments are required to unequivocally prove this link.

Using the established qPCR methodology, we next went on to follow levels of $P$. parvum and its lytic virus, PpDNAV over a 2 year timeframe (Figure 6). Unlike the toxic bloom, which occurred in April 2015, and previous findings of others that suggest blooms of $P$. parvum have no seasonality, ${ }^{20}$ we observed over these 2 years that blooms are strongly correlated with increases in temperature. Large blooms of $P$. parvum were observed in summer months when the temperature was at its highest and leading into autumn (August 2016 and June 2017), with smaller blooms occurring into autumn. During the winter months, when temperatures were low, levels of $P$. parvum remained consistently low. Spikes in intracellular PpDNAV levels appeared to occur directly after the blooms of $P$. parvum until the bloom declined, which suggests that PpDNAV is likely responsible for the demise of blooms of $P$. parvum in this natural environment, according to Lotka-Volterra predator/prey population dynamics. ${ }^{49}$ Interestingly, higher levels of both $P$. parvum and PpDNAV were consistently observed at sampling location 6 compared to other locations, as was seen for the toxic bloom of April 2015, suggesting other factors not considered in this study such as nutrient content or water movement may be contributing to the severity of blooms in this location.

Finally, we sought to develop a practical management strategy for the repeated occurrence of P. parvum blooms on Hickling Broad. Algicides, barley straw, and flocculating clay have previously been shown to be effective in a laboratory setting ${ }^{17-19}$ but have yet to translate to field use possibly due to their high costs or limits of the practical application of these strategies. Conversely, the use of low doses of hydrogen peroxide has previously been shown to be effective at treating large blooms of other toxic algae in natural environments, as well as reducing levels of the toxic metabolites they produce. ${ }^{35,36} \mathrm{We}$ first showed in a laboratory setting that low concentrations (40 $\mathrm{mg} / \mathrm{L}$ ) of $\mathrm{H}_{2} \mathrm{O}_{2}$ are effective at killing dense $P$. parvum cultures. These concentrations of $\mathrm{H}_{2} \mathrm{O}_{2}$ have previously been shown to cause little to no damage to the selected fish species. ${ }^{50,51} \mathrm{We}$ next carried out field trials in a small dyke at the most northerly point of Hickling Broad (Figure 7A), where $\mathrm{H}_{2} \mathrm{O}_{2}$ was applied and water samples were taken at regular intervals to look for the effect of the treatment on $P$. parvum levels and the microbial community composition. We were able to use qPCR to show that levels of $P$. parvum were effectively reduced over the duration of the treatment and recovered to "normal" levels relative to control levels $96 \mathrm{~h}$ after treatment (Figure $7 \mathrm{~B}$ ). Furthermore, we showed that the application of $\mathrm{H}_{2} \mathrm{O}_{2}$ did not dramatically change the overall microbial community, although relative levels of Chlorococcales were particularly reduced by the treatment (Figure 7C). Chroococcales, such as the genera Microcystis and Snowella, are cyanobacteria and known to be susceptible to peroxide treatment. ${ }^{52}$ No adverse effects were noted over the course of the treatment for any macroinvertebrates or aquatic life, but the effects on the microplankton community was not analyzed. Coupled with the low cost of use, these results suggest that low doses of $\mathrm{H}_{2} \mathrm{O}_{2}$ may constitute an effective treatment strategy for blooms of $P$. parvum on Hickling Broad.

In conclusion, the presented study shows that the dynamics and toxicity of $P$. parvum blooms are driven by an interplay of environmental factors, viral interference, and specific toxin production. The results from this study now provide insights for better informed and improved management and mitigation strategies of P. parvum blooms worldwide.

\section{AVAILABILITY OF DATA AND MATERIALS}

Amplicon sequence data generated in this study were deposited to the NCBI Sequence Read Archive (SRA) under BioProject ID PRJNA595342.

\section{ASSOCIATED CONTENT}

\section{SI Supporting Information}

The Supporting Information is available free of charge at https://pubs.acs.org/doi/10.1021/acs.est.1c04742.

Growth curves and DAPI-stained microscope images of $P$. parvum HIK PR1A and PR6H, photos of the study site and hydrogen peroxide trial, $16 \mathrm{~S}$ rRNA microbial community profiles with and without $P$. parvum chloroplast sequences, extracted ion chromatograms for 
prymnesin-B aglycones, effect of varying doses of hydrogen peroxide on laboratory-grown $P$. parvum cell densities, agarose gel image for $16 \mathrm{~S}$ rDNA PCR products from Hickling P. parvum cultures, and $16 \mathrm{~S}$ sequence obtained from P. parvum HIKPPR-1A (PDF)

\section{AUTHOR INFORMATION}

\section{Corresponding Authors}

Ben A. Wagstaff - Department of Biological Chemistry, John Innes Centre, Norwich NR4 7UH, U.K.; Present Address: Department of Chemistry and Manchester Institute of Biotechnology, University of Manchester, Manchester, M1 7DN, U.K; ๑ orcid.org/0000-0003-42988937; Email: ben.wagstaff@manchester.ac.uk

Jennifer Pratscher - School of Environmental Sciences, University of East Anglia, Norwich NR4 7TJ, U.K.; Present Address: Lyell Centre for Earth and Marine Science and Technology, Heriot-Watt University, Edinburgh, EH14 4AP, U.K.; Email: j.pratscher@hw.ac.uk

\section{Authors}

Peter Paolo L. Rivera - School of Biological Sciences, University of East Anglia, Norwich NR4 7TJ, U.K.

Edward S. Hems - School of Environmental Sciences, University of East Anglia, Norwich NR4 7TJ, U.K.

Elliot Brooks - School of Environmental Sciences, University of East Anglia, Norwich NR4 7TJ, U.K.

Martin Rejzek - Department of Biological Chemistry, John Innes Centre, Norwich NR4 7UH, U.K.

Jonathan D. Todd - School of Biological Sciences, University of East Anglia, Norwich NR4 7TJ, U.K.

J. Colin Murrell - School of Environmental Sciences, University of East Anglia, Norwich NR4 7TJ, U.K.

Robert A. Field - Department of Biological Chemistry, John Innes Centre, Norwich NR4 7UH, U.K.; Present Address: Department of Chemistry and Manchester Institute of Biotechnology, University of Manchester, Manchester, M1 7DN, U.K

Complete contact information is available at: https://pubs.acs.org/10.1021/acs.est.1c04742

\section{Author Contributions}

B.A.W. and J.P. contributed equally to this study. B.A.W. and J.P. contributed equally to the article. B.A.W., J.P., P.P.L.R., J.C.M., J.D.T., and R.A.F. designed the series of experiments. B.A.W., E.S.H., M.R., E.B., and J.P. collected samples. B.A.W., E.S.H., M.R., E.B., J.P., and P.P.L.R. performed the experiments. B.A.W., E.S.H., M.R., J.P., and P.P.L.R. performed data analysis. All authors contributed to the development of the manuscript. All authors read and approved the final manuscript.

\section{Funding}

Work at the John Innes Centre is supported by the UK BBSRC Institute Strategic Program on Molecules from NatureProducts and Pathways [BBS/E/J/000PR9790] and the John Innes Foundation. B.A.W. was supported by a BBSRC CASE $\mathrm{PhD}$ studentship with the Environment Agency. J.P. was supported by a NERC Independent Research Fellowship (NE/L010771/2) and Norwich Research Park Science Links Seed Fund (SLSF 32). E.S.H. was supported by a Norwich Research Park DTP PhD Studentship. P.R. was supported by the Newton Fund Scholarship (261863799), a joint program by the British Council and the Commission on Higher Education
(CHED), Philippines. Work in the J.D.T. laboratory was supported by the Natural Environmental Research Council standard grants NE/S001352/1 and NE/P012671/1. J.C.M. research is also supported by the Earth and Life Systems Alliance, Norwich Research Park.

\section{Notes}

The authors declare no competing financial interest.

An early version of this manuscript was published on the preprint server, www.biorxiv.org, at the following URL: https:// www.biorxiv.org/content/10.1101/2020.03.26.010066. ${ }^{56}$ DOI: https://doi.org/10.1101/2020.03.26.010066.

\section{ACKNOWLEDGMENTS}

We thank Gerhard Saalbach for assistance with mass spectrometry. We would also like to thank John Currie, Steven Lane, Andrew Hindes, Gavin Devaney, and other colleagues from the Norfolk and District Pike Club, Environment Agency, Fishtrack Ltd, and the Broads Authority, respectively, for invaluable insights and support.

\section{REFERENCES}

(1) FAO. The State of World Fisheries and Aquaculture 2018-Meeting the Sustainable Development Goals; FAO: Rome Italy, 2018.

(2) Smayda, T. J. What is a bloom? A commentary. Limnol. Oceanogr. 1997, 42, 1132-1136.

(3) Merico, A.; Tyrrell, T.; Brown, C. W.; Groom, S. B.; Miller, P. I. Analysis of satellite imagery for Emiliania huxleyi blooms in the Bering Sea before 1997. Geophys. Res. Lett. 2003, 30, 70-71.

(4) Roelke, D. L.; Barkoh, A.; Brooks, B. W.; Grover, J. P.; Hambright, K. D.; LaClaire, J. W.; Moeller, P. D. R.; Patino, R. A chronicle of a killer alga in the west: ecology, assessment, and management of Prymnesium parvum blooms. Hydrobiologia 2016, 764, 29-50.

(5) Granéli, E.; Edvardsen, B.; Roelke, D. L.; Hagström, J. A. The ecophysiology and bloom dynamics of Prymnesium spp. Harmful Algae 2012, 14, 260-270.

(6) Larsen, A.; Edvardsen, B. Relative ploidy levels in Prymnesium parvum and P. patelliferum (Haptophyta) analyzed by flow cytometry. Phycologia 1998, 37, 412-424.

(7) Larsen, A.; Bryant, S.; Båmstedt, U. Growth rate and toxicity of Prymnesium parvum and Prymnesium patelliferum (haptophyta) in response to changes in salinity, light and temperature. Sarsia 1998, 83, 409-418.

(8) Manning, S. R.; La Claire, J. W. Prymnesins: Toxic Metabolites of the Golden Alga, Prymnesium parvum Carter (Haptophyta). Mar. Drugs 2010, 8, 678-704.

(9) Wang, D.-Z. Neurotoxins from Marine Dinoflagellates: A Brief Review. Mar. Drugs 2008, 6, 349-371.

(10) Chemical studies on prymnesins isolated from Prymnesium parvum. Harmful Marine Algal Blooms: Proceedings of the Sixth International Conference on Toxic Marine Phytoplankton, October 1993; Igarashi, T., Oshima, Y., Murata, M., Yasumoto, T., Eds.; Nantes, France, 1995.

(11) Igarashi, T.; Satake, M.; Yasumoto, T. Prymnesin-2:A Potent Ichthyotoxic and Hemolytic Glycoside Isolated from the Red Tide Alga Prymnesium parvum. J. Am. Chem. Soc. 1996, 118, 479-480.

(12) Igarashi, T.; Satake, M.; Yasumoto, T. Structures and Partial Stereochemical Assignments for Prymnesin-1 and Prymnesin-2:Potent Hemolytic and Ichthyotoxic Glycosides Isolated from the Red Tide Alga Pr. J. Am. Chem. Soc. 1999, 121, 8499-8511.

(13) Rasmussen, S. A.; Meier, S.; Andersen, N. G.; Blossom, H. E.; Duus, J. Ø.; Nielsen, K. F.; Hansen, P. J.; Larsen, T. O. Chemodiversity of Ladder-Frame Prymnesin Polyethers in Prymnesium parvum. J. Nat. Prod. 2016, 79, 2250-2256.

(14) Hems, E. S.; Wagstaff, B. A.; Saalbach, G.; Field, R. A. CuAAC click chemistry for the enhanced detection of novel alkyne-based natural product toxins. Chem. Commun. 2018, 54, 12234-12237. 
(15) Binzer, S. B.; Svenssen, D. K.; Daugbjerg, N.; Alves-de-Souza, C.; Pinto, E.; Hansen, P. J.; Larsen, T. O.; Varga, E. A-, B- and C-type prymnesins are clade specific compounds and chemotaxonomic markers in Prymnesium parvum. Harmful Algae 2019, 81, 10-17.

(16) David Hambright, K.; Beyer, J. E.; Easton, J. D.; Zamor, R. M.; Easton, A. C.; Hallidayschult, T. C. The niche of an invasive marine microbe in a subtropical freshwater impoundment. ISME J. 2015, 9, 256-264.

(17) Hagström, J. A.; Sengco, M. R.; Villareal, T. A. Potential Methods for Managing Prymnesium parvum Blooms and Toxicity, With Emphasis on Clay and Barley Straw: A Review. J. Am. Water Resour. Assoc. 2010, 46, 187-198.

(18) Barkoh, A.; Paret, J. M.; Lyon, D. D.; Begley, D. C.; Smith, D. G.; Schlechte, J. W. Evaluation of Barley Straw and a Commercial Probiotic for Controlling Prymnesium parvum in Fish Production Ponds. N. Am. J. Aquac. 2008, 70, 80-91.

(19) Rodgers, J. H., Jr.; Johnson, B. M.; Bishop, W. M. Comparison of Three Algaecides for Controlling the Density of Prymnesium parvum. J. Am. Water Resour. Assoc. 2010, 46, 153-160.

(20) Holdway, P. A.; Watson, R. A.; Moss, B. Aspects of the ecology of Prymnesium parvum (Haptophyta) and water chemistry in the Norfolk Broads, England. Freshwat Biol 1978, 8, 295-311.

(21) Wagstaff, B. A.; Hems, E. S.; Rejzek, M.; Pratscher, J.; Brooks, E.; Kuhaudomlarp, S.; O’Neill, E. C.; Donaldson, M. I.; Lane, S.; Currie, J.; Hindes, A. M.; Malin, G.; Murrell, J. C.; Field, R. A. Insights into toxic Prymnesium parvum blooms: the role of sugars and algal viruses. Biochem. Soc. Trans. 2018, 46, 413-421.

(22) Broads Authority. Broads Plan 2017, 2017.

(23) Wagstaff, B.; Vladu, I.; Barclay, J.; Schroeder, D.; Malin, G.; Field, R. Isolation and Characterization of a Double Stranded DNA Megavirus Infecting the Toxin-Producing Haptophyte Prymnesium parvum. Viruses 2017, 9, 40.

(24) Bürgmann, H.; Widmer, F.; Sigler, W. V.; Zeyer, J. mRNA extraction and reverse transcription-PCR protocol for detection of nifH gene expression by Azotobacter vinelandii in soil. Appl. Environ. Microbiol. 2003, 69, 1928.

(25) Caporaso, J. G.; Lauber, C. L.; Walters, W. A.; Berg-Lyons, D.; Huntley, J.; Fierer, N.; Owens, S. M.; Betley, J.; Fraser, L.; Bauer, M.; Gormley, N.; Gilbert, J. A.; Smith, G.; Knight, R. Ultra-high-throughput microbial community analysis on the Illumina HiSeq and MiSeq platforms. ISME J. 2012, 6, 1621.

(26) Caporaso, J. G.; Kuczynski, J.; Stombaugh, J.; Bittinger, K.; Bushman, F. D.; Costello, E. K.; Fierer, N.; Peña, A. G.; Goodrich, J. K.; Gordon, J. I.; Huttley, G. A.; Kelley, S. T.; Knights, D.; Koenig, J. E.; Ley, R. E.; Lozupone, C. A.; McDonald, D.; Muegge, B. D.; Pirrung, M.; Reeder, J.; Sevinsky, J. R.; Turnbaugh, P. J.; Walters, W. A.; Widmann, J.; Yatsunenko, T.; Zaneveld, J.; Knight, R. QIIME allows analysis of high-throughput community sequencing data. Nat. Methods 2010, 7, 335.

(27) Galluzzi, L.; Bertozzini, E.; Penna, A.; Perini, F.; Pigalarga, A.; Graneli, E.; Magnani, M. Detection and quantification of Prymnesium parvum (Haptophyceae) by real-time PCR. Lett. Appl. Microbiol. 2008, 46, 261.

(28) Zamor, R. M.; Glenn, K. L.; Hambright, K. D. Incorporating molecular tools into routine $\mathrm{HAB}$ monitoring programs: Using qPCR to track invasive Prymnesium. Harmful Algae 2012, 15, 1-7.

(29) Ludwig, W.; Strunk, O.; Westram, R.; Richter, L.; Meier, H.; Yadhukumar; Buchner, A.; Lai, T.; Steppi, S.; Jobb, G.; Förster, W.; Brettske, I.; Gerber, S.; Ginhart, A. W.; Gross, O.; Grumann, S.; Hermann, S.; Jost, R.; König, A.; Liss, T.; Lüssmann, R.; May, M.; Nonhoff, B.; Reichel, B.; Strehlow, R.; Stamatakis, A.; Stuckmann, N.; Vilbig, A.; Lenke, M.; Ludwig, T.; Bode, A.; Schleifer, K. H. ARB: a software environment for sequence data. Nucleic Acids Res. 2004, 32, $1363-1371$.

(30) Guillard, R. R. L.; Ryther, J. H. Studies of marine planktonic diatoms: I. Cyclotella nana Hustedt, and Detonula confervacea (Cleve) Gran. Can. J. Microbiol. 1962, 8, 229-239.

(31) Andersen, R. A.; Kawachi, M. Microalgae isolation techniques. Algal Culturing Techniques; Academic Press, 2005; Vol. 83.
(32) Porter, K. G.; Feig, Y. S. The use of DAPI for identifying and counting aquatic microflora. Limnol. Oceanogr. 1980, 25, 943-948.

(33) Manning, S. R.; La Claire, J. W. Isolation of polyketides from Prymnesium parvum (Haptophyta) and their detection by liquid chromatography/mass spectrometry metabolic fingerprint analysis. Anal. Biochem. 2013, 442, 189-195.

(34) Baker, J. W.; Grover, J. P.; Brooks, B. W.; Ureña-Boeck, F.; Roelke, D. L.; Errera, R.; Kiesling, R. L. Growth and toxicity of Prymnesium parvum (haptophyta) as a function of salinity, light, and temperature. J. Phycol. 2007, 43, 219-227.

(35) Matthijs, H. C. P.; Visser, P. M.; Reeze, B.; Meeuse, J.; Slot, P. C.; Wijn, G.; Talens, R.; Huisman, J. Selective suppression of harmful cyanobacteria in an entire lake with hydrogen peroxide. Water Res. 2012, 46, 1460-1472.

(36) Burson, A.; Matthijs, H. C. P.; de Bruijne, W.; Talens, R.; Hoogenboom, R.; Gerssen, A.; Visser, P. M.; Stomp, M.; Steur, K.; van Scheppingen, Y.; Huisman, J. Termination of a toxic Alexandrium bloom with hydrogen peroxide. Harmful Algae 2014, 31, 125-135.

(37) Phillips, G.; Bennion, H.; Perrow, M. R.; Sayer, C. D.; Spears, B. M.; Willby, N. Hickling Broad Dossier. Part of the Review of Lake Restoration Practises and Their Performance in the Broads National Park, 1980-2013; Report for Broads Authority: Norwich and Natural England, 2016.

(38) Galluzzi, L.; Bertozzini, E.; Penna, A.; Perini, F.; Pigalarga, A.; Graneli, E.; Magnani, M. Detection and quantification of Prymnesium parvum (Haptophyceae) by real-time PCR. Lett. Appl. Microbiol. 2008, 46, 261-266.

(39) Roelke, D. L.; Grover, J. P.; Brooks, B. W.; Glass, J.; Buzan, D.; Southard, G. M.; Fries, L.; Gable, G. M.; Schwierzke-Wade, L.; Byrd, M.; Nelson, J. A decade of fish-killing Prymnesium parvum blooms in Texas: roles of inflow and salinity. J. Plankton Res. 2011, 33, 243-253.

(40) Jones, A. C.; Liao, T. S. V.; Najar, F. Z.; Roe, B. A.; Hambright, K. D.; Caron, D. A. Seasonality and disturbance: annual pattern and response of the bacterial and microbial eukaryotic assemblages in a freshwater ecosystem. Environ. Microbiol. 2013, 15, 2557-2572.

(41) Acosta, F.; Zamor, R. M.; Najar, F. Z.; Roe, B. A.; Hambright, K. D. Dynamics of a microbial invasion. Proc. Natl. Acad. Sci. U.S.A. 2015, 112, 11594-11599.

(42) Green, D. H.; Echavarri-Bravo, V.; Brennan, D.; Hart, M. C. Bacterial Diversity Associated with the Coccolithophorid algae Emiliania huxleyi and Coccolithus pelagicus f. braarudii. BioMed Res. Int. 2015, 2015, 194540.

(43) Jones, A. C.; Hambright, K. D.; Caron, D. A. Ecological Patterns Among Bacteria and Microbial Eukaryotes Derived from Network Analyses in a Low-Salinity Lake. Microb. Ecol. 2018, 75, 917-929.

(44) Driscoll, W. W.; Espinosa, N. J.; Eldakar, O. T.; Hackett, J. D. Allelopathy as an emergent, exploitable public good in the bloomforming microalga Prymnesium parvum. Evolution 2013, 67, 15821590.

(45) Bertin, M. J.; Zimba, P. V.; Beauchesne, K. R.; Huncik, K. M.; Moeller, P. D. R. The contribution of fatty acid amides to Prymnesium parvum Carter toxicity. Harmful Algae 2012, 20, 117-125.

(46) Henrikson, J. C.; Gharfeh, M. S.; Easton, A. C.; Easton, J. D.; Glenn, K. L.; Shadfan, M.; Mooberry, S. L.; Hambright, K. D.; Cichewicz, R. H. Reassessing the ichthyotoxin profile of cultured Prymnesium parvum (golden algae) and comparing it to samples collected from recent freshwater bloom and fish kill events in North America. Toxicon 2010, 55, 1396-1404.

(47) Remmel, E. J.; Hambright, K. D. Toxin-assisted micropredation: experimental evidence shows that contact micropredation rather than exotoxicity is the role of Prymnesium toxins. Ecol. Lett. 2012, 15, 126132.

(48) La Claire, J. W.; Manning, S. R.; Talarski, A. E. Semi-quantitative assay for polyketide prymnesins isolated from Prymnesium parvum (Haptophyta) cultures. Toxicon 2015, 102, 74-80.

(49) Yorke, J. A.; Anderson, W. N. Predator-Prey Patterns. Proc. Natl. Acad. Sci. U.S.A. 1973, 70, 2069-2071. 
(50) Rach, J. J.; Schreier, T. M.; Howe, G. E.; Redman, S. D. Effect of species, life stage, and water temperature on the toxicity of hydrogen peroxide to fish. Progress. Fish Cult. 1997, 59, 41-46.

(51) Avendaño-Herrera, R.; Magariños, B.; Irgang, R.; Toranzo, A. E. Use of hydrogen peroxide against the fish pathogen Tenacibaculum maritimum and its effect on infected turbot (Scophthalmus maximus). Aquaculture 2006, 257, 104-110.

(52) Ding, Y.; Gan, N.; Li, J.; Sedmak, B.; Song, L. Hydrogen peroxide induces apoptotic-like cell death in Microcystis aeruginosa (Chroococcales, Cyanobacteria) in a dose-dependent manner. Phycologia 2012, 51, 567-575.

(53) Smalley, N. E.; Taipale, S.; De Marco, P.; Doronina, N. V.; Kyrpides, N.; Shapiro, N.; Woyke, T.; Kalyuzhnaya, M. G. Functional and genomic diversity of methylotrophic Rhodocyclaceae: description of Methyloversatilis discipulorum sp. nov. Int. J. Syst. Evol. Microbiol. 2015, 65, 2227-2233.

(54) Khan, S. T.; Fukunaga, Y.; Nakagawa, Y.; Harayama, S. Emended descriptions of the genus Lewinella and of Lewinella cohaerens, Lewinella nigricans and Lewinella persica, and description of Lewinella lutea sp. nov. and Lewinella marina sp. nov. Int. J. Syst. Evol. Microbiol. 2007, 57, 2946-2951.

(55) Chen, Y.-L.; Lee, C.-C.; Lin, Y.-L.; Yin, K.-M.; Ho, C.-L.; Liu, T. Obtaining long 16S rDNA sequences using multiple primers and its application on dioxin-containing samples. BMC Bioinf. 2015, 16, S13.

(56) Wagstaff, B. A.; Pratscher, J.; Rivera, P. P.; Hems, E. S.; Brooks, E.; Rejzek, M.; Todd, J. D.; Murrell, J. C.; Field, R. A. Dissecting the toxicity and mitigating the impact of harmful Prymnesium blooms in the UK waters of the Norfolk Broads. 2020, bioRxiv. 2020.03.26.010066. 